\title{
EARLY HOLOCENE ALLUVIA IN THE LOWER WISLOK RIVER VALLEY AND THEIR CHRONOSTRATIGRAPHY IN THE LIGHT OF RADIOCARBON DATINGS AND PALYNOLOGICAL ANALYSIS
}

\author{
SŁAWOMIR SUPERSON ${ }^{1}$, PIOTR GĘBICA ${ }^{2}$, ADAM MICHCZYŃSKI ${ }^{3}$, \\ PIOTR KOLACZEK ${ }^{4}$ and KAZIMIERZ SZCZEPANEK ${ }^{5}$ \\ ${ }^{1}$ Pedagogical University in Kraków, ul. Podchorażych 2, 30-084 Kraków, Poland \\ ${ }^{2}$ University of Information Technology and Management in Rzeszów, ul. Sucharskiego 2, 35-225 Rzeszów, Poland \\ ${ }^{3}$ Department of Radioisotopes, Silesian University of Technology in Gliwice, Konarskiego 22B, 44-100 Gliwice, Poland \\ ${ }^{4}$ Department of Biogeography and Paleoecology, Faculty of Geographical and Geological Sciences, Adam Mickiewicz University in \\ Poznań, Krygowskiego 10, 61-680 Poznań, Poland \\ ${ }^{5}$ Department of Palaeobotany and Palaeoherbarium, Faculty of Biology and Earth Sciences, Jagiellonian University in Kraków, \\ Lubicz 46, Krakow, 31-512, Poland
}

\begin{abstract}
The paper presents the results of the latest radiocarbon dating and the palynological analyses of organic sediments found in the alluvia of the Wisłok River valley between the towns of Łańcut and Przeworsk. The study conducted in the gravel pit made possible the dating of several alluvial fills of the 7-8 $\mathrm{m}$ high Holocene terrace and the 5-6 m high floodplain. The oldest channel alluvia and palaeochannel sediments of the 7-8 m high terrace were dated at 10 100-9300 BP (11 960$10500 \mathrm{cal} \mathrm{BP}$ ). According to the anthracological analysis the top cover of clay overbank alluvia, which bears charcoal fragments, was deposited in the Subboreal and/or the Subatlantic Phases. In the sequence of the 5-6 m high floodplain, the bottom fills of palaeochannels, dated at 10 195-9885 cal BP (probability level: 68.2\%; GdS-3233: $8900 \pm 95$ BP ) and 11 095-10 755 cal BP (probability level: $68.2 \%$; GdS-3228: $9575 \pm 95 \mathrm{BP}$ ), were truncated by erosion and covered by alluvia of palaeomeanders, which were active in the $19^{\text {th }}$ century. Preservation of the erosional bench of the Early Holocene organic sediments indicates the predomination of lateral migration of the river channel during the last 200 years and the formation of wide erosional floodplain that has been aggraded with recent flood alluvia. In the $20^{\text {th }}$ century the floodplain aggradation was simultaneous with the deepening of the Wisłok riverbed.
\end{abstract}

Keywords: alluvia, chronostratigraphy, Early Holocene, radiocarbon dating, palynology. 


\section{INTRODUCTION}

The Holocene alluvia within the Wisłok River valley were described for the first time more than 100 years ago by Friedberg (1903). Between Rzeszów and Trzebownisko L. Starkel (1960) distinguished several alluvial fills from the Late Glacial and the Holocene dated by the palynological method by K. Mamakowa. The current recognition of the stratigraphy of the Vistulian (Weichselian) and the Holocene alluvia of the lower Wisłok River valley is based on more than 30 radiocarbon and palynological age determinations of the sequences located mostly between Łukawiec and Łaka villages and the town of Łańcut (Gębica et al., 2002, 2009; Gębica, 2004. 2011; Kołaczek, 2007, 2010) (Fig. 1B).

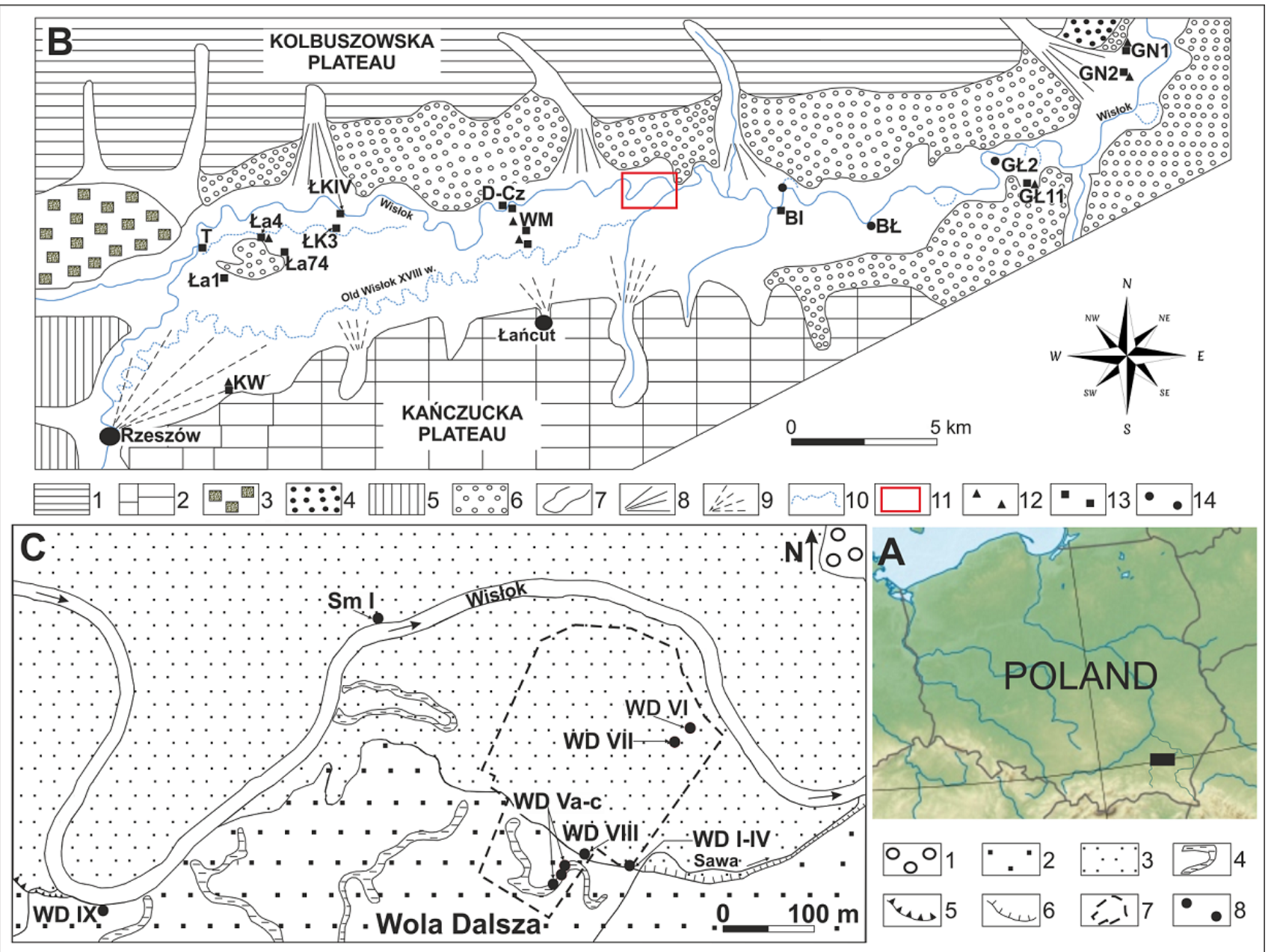

Fig. 1. Maps with location and geomorphology of study area.

\section{A. General location of the study area.}

B. The Wisłok River valley and the Late Glacial and Holocene alluvia with sites sampled for the radiocarbon datings (elaborated by P. Gębica). Explanation of symbols: 1 - Kolbuszowska Plateau covered with sediments of the Elsterian Glaciation, 2 - Kańczucka Plateau covered with Saalian 2 (Wartanian) and Vistulian loess, 3 - fluvioglacial plain, Elsterian 2 Glaciation, 4 - river terrace 13-18 m high, Saalian 2 (Wartanian), 5- loess terrace 15-20 m high, Vistulian, 6-Vistulian (sandy) terrace 8-12 m high, with dunes, 7- erosional-denudation valley, 8 - Pleistocene alluvial fan, 9 - Holocene alluvial fan, 10 - Holocene floodplain 7-8 m high and systems of palaeochannels, 11- study area, 12 - sites of the Late Glacial sediments, 13 - sites of the Early Holocene sediments, 14 - sites of the Last Millenium sediments. List of the sites dated by radiocarbon and palynological methods: St - Słocina, KW - Krasne-Wólka, Ła1 - Łaka 1, Ła4 - Łaka 4, $T$ - Terliczka, Ła 74 - Łąka archaeological site No. 74, ŁkIV - Łukawiec IV, Łk3 - Łukawiec 3, CzP - Czarna Podbór, D-Cz - Dabrówki- Czarna, WM - Wola Mała, BI - Białobrzegi, BŁ - Budy Łańcuckie, GŁ2 - Gniewczyna Łańcucka 2, GŁ11 - Gniewczyna Łańcucka 11, GN1 - Grodzisko Nowe 1, GN2 - Grodzisko Nowe (Dolne) 2.

C. Wola Dalsza gravel pit and the location of sequences described in the text (elaborated by S. Superson). Explanation of symbols: 1 - Vistulian sandy terrace 8-12 m high, 2 - Holocene terrace 7-8 m high, 3-floodplain 5-6 m high, 4-palaeochannels, 5 - erosional edges higher than $1 \mathrm{~m}$, 6 - erosional edges up to $1 \mathrm{~m}$ high, 7 - extent of gravelpit, 8 - study sites, Sm - Smolarzyny site. 
The study of recently outcropped depositional sequences located in the erosional undercuts of the Wisłok riverbed and in the gravel pits recently opened due to the construction of the A-4 highway, made it possible to recognise the structure and the stratigraphy of the Wisłok River valley alluvia between the towns of Łańcut and Przeworsk (Gębica et al., 2014; Superson, 2014; Superson et al., 2016). Therefore, the objective of the related study is the reconstruction of chronostratigraphy of the Holocene alluvia in the Wisłok River valley with particular emphasis on the position, genesis and age of the Early Holocene organic sediments dated by the radiocarbon method and palynological analysis. An attempt was also made to explain the preservation of the erosional bench formed of the Early Holocene organic sediments within the 5-6 m high floodplain in the context of historical changes of the Wisłok River channel. Moreover, one of the considered palaeogeographic problems is the functioning of rivers in the Early Holocene (10 200-8600 BP; $11500-9500$ cal BP), which was characterised by the stabilisation expressed by lower frequency of flood occurrence (Starkel, 1995, 2001) in this period and at the same time the intensification of organic accumulation.

\section{STUDY AREA}

The Wisłok River is the longest tributary of the San River. In the $40 \mathrm{~km}$ long section it flows along the latitudinal erosional depression named the Fore-Carpathian Trough (Rynna Podkarpacka) (Starkel, 1972), through which during the San 2 (Elsterian) glaciation glacial waters flowed eastward toward the Dniester River basin. The bottom of the valley, eroded in Miocene clays is covered with Vistulian (Weichselian) and Holocene alluvia. The terraced floor of the valley is framed from the south and the north by the edges of the plateaus (Fig. 1B). Between the towns of Rzeszów and Łańcut the 4-6 km wide Holocene valley floor is covered in the southern part by a system of paleochannels of the Old Wisłok (Stary Wisłok) River (Fig. 1B), while in its northern part the present Wisłok River channel is located after its avulsion in the middle of the $18^{\text {th }}$ century (Strzelecka, 1958). Both parts of the valley, filled up with the Late Vistulian and Holocene alluvia, are separated by an erosional remnant of the Vistulian terrace (Gębica, 2004). To the east of Łańcut the area occupied by this terrace increases, the width of the valley bottom ranges from 3 to $4 \mathrm{~km}$, while the floodplain width ranges from 0.8 to $1.5 \mathrm{~km}$.

The study area is situated in the northern part of the Fore-Carpathian Trough, in the village of Wola Dalsza, about $5 \mathrm{~km}$ north-east of Łańcut (Fig. 1B). On a crosssection of the valley, through the area of this village, a Vistulian terrace covered by dunes with a height of 8-12 $\mathrm{m}$ (above the riverbed), a 7-8 $\mathrm{m}$ high terrace and a 5-6 m high floodplain occur. In the $1.3 \mathrm{~km}$ wide floodplain numerous paleomeanders occur. The apparent erosional edge of paleochannel visible on Fig. 1C, which separates the 7-8 $\mathrm{m}$ high terrace from the floodplain, marks the location of the Wisłok channel in the 70-ties of $19^{\text {th }}$ century (Special map, 1878).

\section{MATERIALS AND METHODS}

After an initial survey of the accessible outcrops, 8 sequences located using the GPS (Global Positioning System) system were selected for further detailed examination and sampling. At the selected sites the sequences up to 7-8 $\mathrm{m}$ long in the outcrops were described and supplemented with archival bore-hole data up to the length of 11-13 m. Moreover, the sequences at the neighbouring sites in the village of Smolarzyny were examined in detail. 13 samples of peat, organic silt, charcoal as well as fragments of wood and tree trunks were collected. Five of these samples were dated by the radiocarbon method in the Department of Radioisotopes, Silesian University of Technology in Gliwice (Lab. code begins with GdS). One sample of fossil tree trunk, taken from the outcrop in the Wisłok floodplain at a distance of $1 \mathrm{~km}$ west of the gravel pit (Fig. 1C) was dated by the radiocarbon method in the Laboratory of Absolute Dating in Skała near Cracow (Lab. code begins with MKL) (Table 1). The sample for the palynological analysis was taken from the Smolarzyny sequence.

Consequently, the following 8 samples of organic deposits were selected for conventional radiocarbon dating (LSC) of: one sample of charcoal, 3 peat samples, 3 wood samples and one sample of fired clay with coal dust. However, the content of organic material in this last sample was too small for dating using the conventional technique. Furthermore, the charcoal sample of a weight of $1 \mathrm{~g}$ was too small for reliable conventional dating. Therefore finally, the reliable results of 6 age determinations were taken into account and are presented in Table 1.

All samples underwent the standard procedure of initial preparation acid-alkali-acid, and then they were decomposed and converted into benzene (Pazdur et al., 2003). The radiocarbon dating was performed applying a liquid scintillation technique (LSC method) and using alpha/beta spectrometers: Quantulus 1220 and ICELS (Pawlyta et al., 1998; Tudyka and Pazdur, 2010; Tudyka et al., 2015). Calibration of radiocarbon dates was carried out using the computer calibration program OxCal 4.2 (Bronk Ramsey et al., 2010) based on the calibration curve IntCal13 (Reimer et al., 2013).

The palynological analysis was used for the verification of the age of the sediments determined by radiocarbon dating. Therefore, this analysis was performed for 6 samples taken from 6 depositional sequences of the 7-8 $\mathrm{m}$ high terrace and the floodplain, which were also dated by the radiocarbon method. Furthermore, the tree species composition of charcoal fragments in the overbank sediments was examined. The species identification of charcoal fragments was based on anatomic wood structure. The charcoal fragments were prepared for micro- 
S. Superson et al.

Table 1. Radiocarbon datings of samples from the sequence in the Wola Dalsza gravel-pit.

\begin{tabular}{|c|c|c|c|c|c|c|c|c|}
\hline $\begin{array}{l}\text { Sample } \\
\text { no. }\end{array}$ & $\begin{array}{l}\text { Name of the } \\
\text { profile }\end{array}$ & $\begin{array}{c}\text { Terrace } \\
\text { level } \\
\text { (m) }\end{array}$ & $\begin{array}{l}\text { Dated } \\
\text { material }\end{array}$ & $\begin{array}{l}\text { Depth } \\
\text { (m) }\end{array}$ & $\begin{array}{l}\text { Laboratory } \\
\text { no. }\end{array}$ & $\begin{array}{l}\text { Age }{ }^{14} \mathrm{C} \\
\text { (BP) }\end{array}$ & $\begin{array}{c}\text { Calendar Age } \\
\text { (calibrated) } \\
\text { range } 68 \%\end{array}$ & $\begin{array}{c}\text { Calendar Age } \\
\text { (calibrated) } \\
\text { range } 95 \%\end{array}$ \\
\hline 1 & Wola Dalsza Vb & $7-8$ & charcoals & $0.60-0.80$ & --------- & no dated & --------- & ---------- \\
\hline 2 & Wola Dalsza Va & $7-8$ & coal dust & $1.50-1.60$ & - & no dated & - & - \\
\hline 3 & Wola Dalsza Vc & $7-8$ & wood & $4.60-4.65$ & GdS-1920 & $10100 \pm 140$ & $\begin{array}{l}11960-11860 \text { cal BP }(11.2 \%) \\
11845-11395 \text { cal BP }(57.0 \%)\end{array}$ & $\begin{array}{c}12370-12350 \text { cal BP }(0.3 \%) \\
12235-12205 \text { cal BP }(0.5 \%) \\
12170-11235 \text { cal BP }(94.5 \%)\end{array}$ \\
\hline 4 & Wola Dalsza IX & $7-8$ & trunk & $5.80-5.90$ & MKL-2786 & $9290 \pm 50$ & $8619-8466$ cal BC (68.2\%) & $\begin{array}{l}8699-8679 \text { cal BC }(1.8 \%) \\
8641-8337 \text { cal BC }(93.6 \%)\end{array}$ \\
\hline 5 & Wola Dalsza IV & $5-6$ & peat & $3.20-3.25$ & GdS-3233 & $8900 \pm 95$ & $10195-9885$ cal BP (68.2\%) & $10230-9695$ cal BP (95.4\%) \\
\hline 6 & Wola Dalsza VI & $5-6$ & trunk & $3.00-3.10$ & GdS-3230 & $7390 \pm 80$ & $\begin{array}{c}8335-8155 \text { cal BP }(64.8 \%) \\
8085-8065 \text { cal BP }(3.4 \%)\end{array}$ & 8365-8030 cal BP (95.4\%) \\
\hline 7 & Wola Dalsza VII & $5-6$ & peat & $4.70-4.80$ & GdS-3056 & $9085 \pm 65$ & $\begin{array}{l}10370-10355 \text { cal BP }(2.9 \%) \\
10300-10185 \text { cal BP }(65.3 \%)\end{array}$ & $\begin{array}{c}10490-10455 \text { cal BP }(1.5 \%) \\
10440-10155 \text { cal BP }(93.9 \%)\end{array}$ \\
\hline 8 & Wola Dalsza VIII & $5-6$ & peat & $4.50-4.60$ & GdS-3228 & $9575 \pm 95$ & $\begin{array}{l}11095-10915 \mathrm{cal} \mathrm{BP}(37.0 \%) \\
10910-10755 \mathrm{cal} \mathrm{BP}(31.2 \%)\end{array}$ & $\begin{array}{l}11195-10655 \text { cal BP }(95.1 \%) \\
10615-10605 \text { cal BP }(0.3 \%)\end{array}$ \\
\hline
\end{tabular}

scopic observation by cutting them along three anatomic cross-sections characteristic for botanic material: transversal, longitudinal-radial and tangential longitudinal. In order to record all anatomic details characteristic for particular tree species examination of fragments larger than $4 \mathrm{~mm}^{3}$ is recommended, nevertheless, smaller but accurately preserved particles are usually also identifiable (Chabal et al., 1999). The charcoal fragments were examined in a metalographic microscope Zeiss AXIO Lab. A1 using a magnification from 100 up to 500 times, and then comparing the pictures with anatomic codes (Schweingruber, 1982, 1990) and specimens from the comparison collection in the Palaeobotanic Department of the W. Szafer Institute of Botany, Polish Academy of Sciences in Krakow.

Moreover, in the south-east face of the gravel pit in the profie WD IV the organic (peat) sequence of undisturbed fabric (vertical column) $57 \mathrm{~cm}$ long was sampled in order to perform palynological analysis. From the sequence WD IV four samples were analysed (Fig. 1C), while in the two neighbouring sequences (WD III and WD I) additional two samples were analysed. The results of these analyses were used for the construction of the simplified palynological diagrams (Fig. 4), which illustrate the composition and the percentage of plant species. The samples were prepared using standard laboratory procedures (Berglund and Ralska-Jasiewiczowa, 1986).

Furthermore, the cartographic materials that were produced in 1878, 1900, 1938 in the scale $1: 100000$ (Topographic map, 1938) and 1:75000 (Special map $1878,1900)$, illustrate the changes in the Wisłok River channel development in $19^{\text {th }}$ and $20^{\text {th }}$ centuries.

\section{RESULTS AND INTERPRETATION}

\section{Characteristics of alluvial fills}

The structure of the 7-8 $\mathrm{m}$ high terrace is tripartite. Its substratum is formed of Miocene clays (LaskowskaWysoczańska, 1971; Gębica, 2004). At a depth of 11$13 \mathrm{~m}$ these clays are overlain by $5-7 \mathrm{~m}$ thick sand-gravel channel alluvia that bear overbank silt inserts and wood fragments (Fig. 2). The macroscopic description of their structural and textural features were described and 70 samples were collected, however, the granulation (grain size) analysis has not been made, yet. The younger fill is formed of sands, that are fine- and medium-grained and through cross-bedded. The higher part of the sequence (WD V and WD IX) is formed of clays and clayey silts of massive structure up to $3 \mathrm{~m}$ thick, underlined by flood rhythmite layer. In the sequence bottom sandgravel through cross-bedded alluvia occur that are inserted with silts. The youngest unit is represented by clays filling the overflow channels. These clays bear charcoal fragments. The erosional bench within the floodplain is formed of peat sediments truncated by erosion, which are outcropped in several sites of the distal part of the floodplain. Peat sediments were accumulated in paleochannels. They are covered by sands and silts horizontally bedded (Fig. 3). In the sequence IVa the peat is overlain with fine and medium grained sands, whereas in other sequences (Fig. 3) the peat sediments are directly overlain by clayey silts. In the proximal part of the floodplain channel sands occur that are through cross-bedded (Fig. 2). They are overlain by sand-silt alluvia of the natural levee $3 \mathrm{~m}$ thick with ascending ripple marks. Within the boundary zone between the channel and the overbank alluvia tree trunks and wood fragments were found (Fig. 2). 


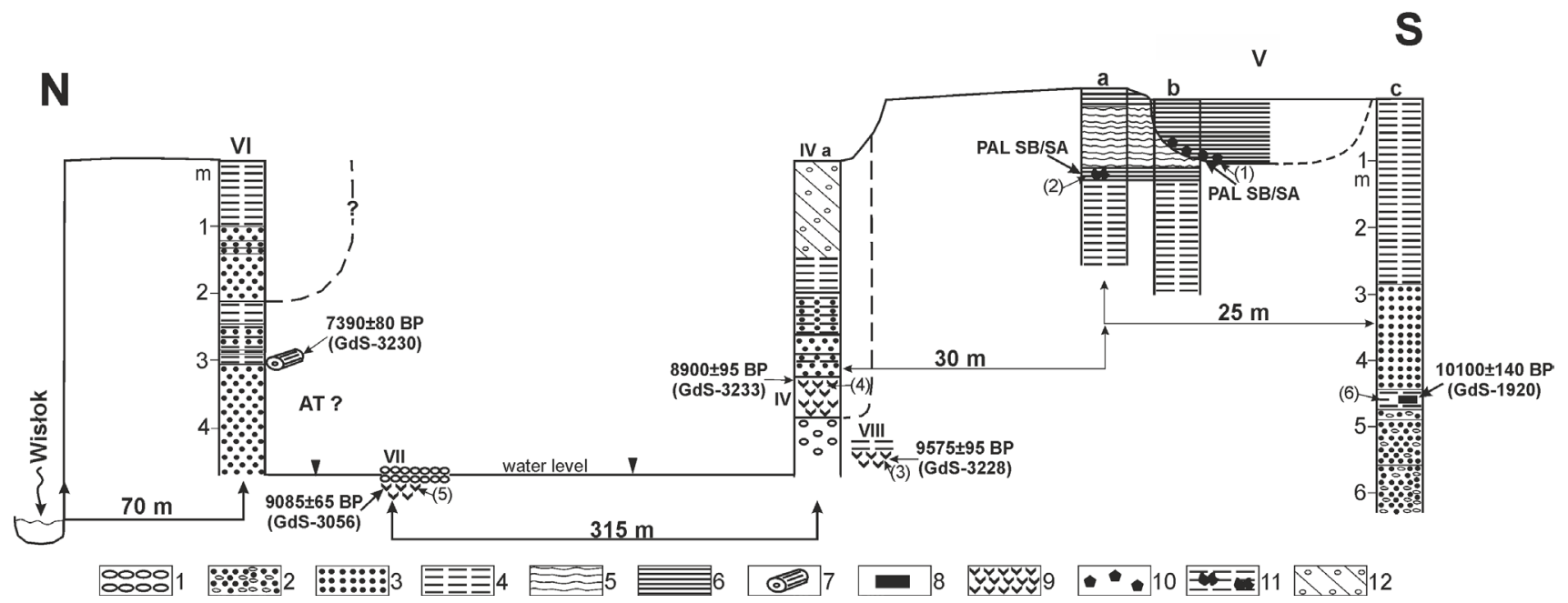

Fig. 2. Geological cross-section of the floodplain (5-6 $\mathrm{m}$ high) and terrace 7-8 $\mathrm{m}$ high with the location of the sequences and samples dated by the radiocarbon and palynological methods (elaborated by S. Superson). Explanation of symbols: 1 - gravel, 2 - sand with single pebbles, 3 - sand, 4 - silt, 5 - flood rhytmithe, 6 - clay, 7 - tree trunks, 8 - wood fragments, 9 - peat, 10 - charcoal fragments, 11 - fired clay bearing coal dust, 12 - anthropogenic embankment; PAL-palynological dating, AT-Atlantic, SB- Subboreal, SA- Subatlantic

E

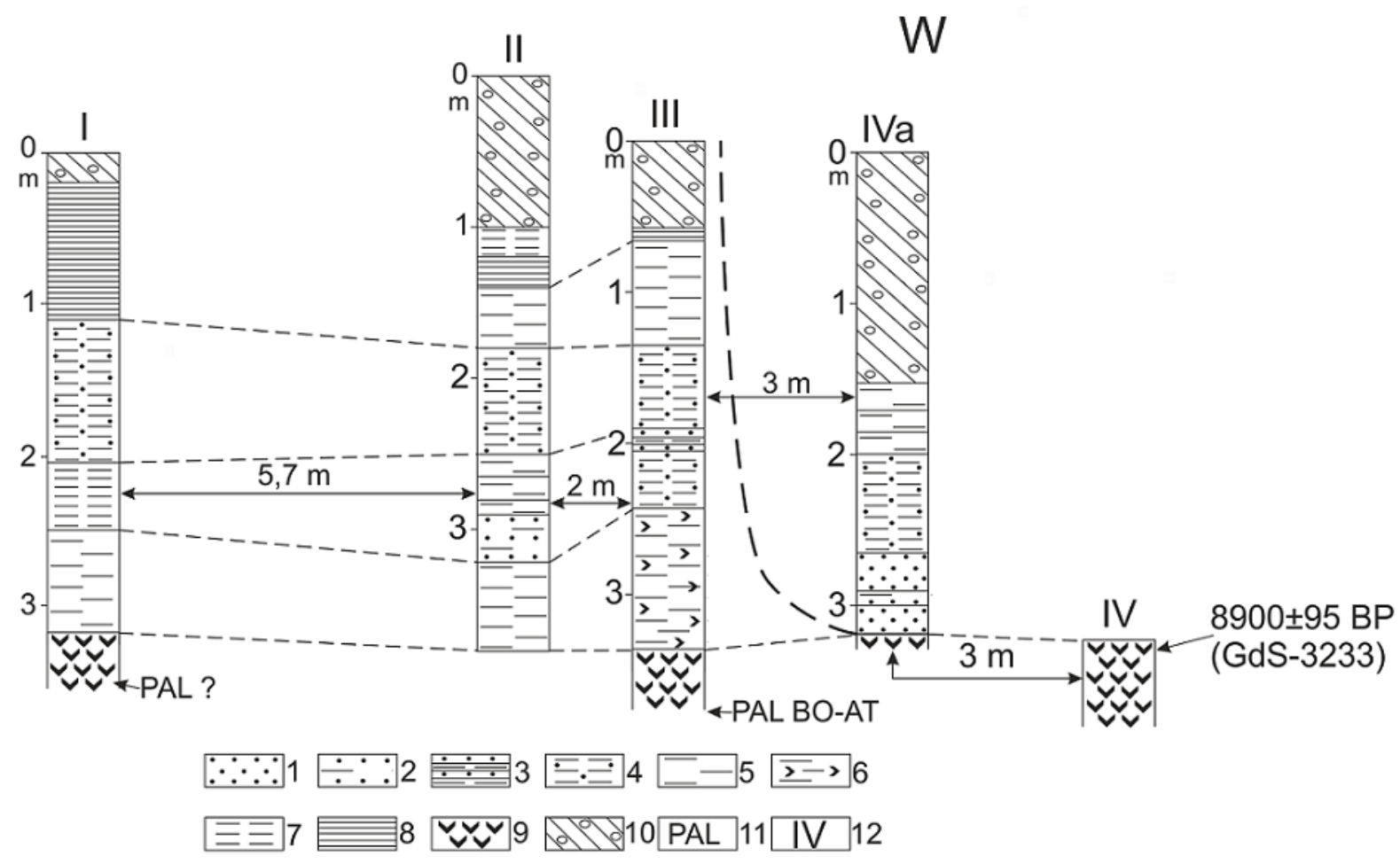

Fig. 3. The structure of floodplain 5-6 m high bearing peat, eroded in the sequence IV (elaborated by S. Superson and P. Gębica). Explanation of symbols: 1 - sand, 2 - silty sand, 3 - laminated sand, 4 - silt with sand, 5 - silt, 6 - organic silt, 7 - clayey silt, 8 - clay, 9 - peat, 10 - anthropogenic embankment, 11 - palynological analysis, 12 - number of the sequence; Bo-Boreal, AT-Atlantic. 


\section{Palynological analysis}

The peat samples taken in the outcrops of the floodplain sediments (sequences WD IV, VII, VIII and Sm I) (Figs. 1C, 3), are characterised by very similar pollen spectra abounding with scots pine (Pinus sylvestris type), birch trees (Betula), willow (Salix), elm (Ulmus) and oak (Quercus), which indicates the peat deposition during the Preboreal or Boreal Phases (Klimek et al., 2006; Kołaczek, 2010, 2011). The silt sample with wood fragments and organic matter from a depth of 4.60-4.65 m (sequence $\mathrm{Vc}$ ) does not contain pollen grains (Table 2). At the top of the 7-8 $\mathrm{m}$ high terrace clay sediments of the shallow channel fills with charcoal horizon were examined. In the sample of these sediments taken at a depth of $0.6-0.8 \mathrm{~m}$ no pollen grains were found, while the charcoal fragments represent oak (Quercus), hornbeam (Carpinus) and ash (Fraxinus) (Table 2).

At a depth of $1.5 \mathrm{~m}$, under the flood rhythmite layer, coal dust occurs on the surface of and inside hard clay aggregates that resemble fossilized/carbonized wood (Fig. 2, Va sequence). On the basis of anthracological analysis the age of the samples bearing charcoal fragments can be ascribed to the Subboreal and/or the Subatlantic Phase.

Up to now four samples taken from WD-IV sequence of the peat have been analysed. The sample from a depth of $3.79 \mathrm{~m}$ is characterised by low pollen concentration, but by high content of redeposited pine pollen grains (see Pinus redeposited on Figs. 3, 4A) and spores of fungi of Glomeromycota division, which proves the intensive supply of terrestrial material (Kołaczek et al., 2013). The samples from a depth of 3.52 and $3.49 \mathrm{~m}$ represent the period of pine (Pinus) and birch (Betula) predomination in the surrounding forests, however, the lack of the above-mentioned fungi and corroded pollen grains suggests smooth deposition of organic material in an oxbowlake. In the top sample from a depth of $3.23 \mathrm{~m}$ the increase in elm (Ulmus) tree content is recorded that coexisted in the forests with pine (Pinus) and birch (Betula). This enables attributing this sample to the Preboreal Phase (Klimek et al., 2006; Kołaczek, 2010, 2011). The sample from a depth of $3.50 \mathrm{~m}$ in the sequence WD I (Fig. 3) is characterised by a very high content of willow

Table 2. The results of palynological analysis (amount of pollen grain) of six samples of organic sediments from the Wola Dalsza site (analysed by K. Szczepanek).

\begin{tabular}{|c|c|c|c|c|c|c|}
\hline $\begin{array}{r}\text { Profile number } \\
\text { Sample number } \\
\text { depth }(\mathrm{m})\end{array}$ & $\begin{array}{c}\mathrm{Vb} \\
1 \\
0.6-0.8\end{array}$ & $\begin{array}{c}\mathrm{Va} \\
2 \\
1.5-1.6\end{array}$ & $\begin{array}{c}\text { VIII } \\
3 \\
4.5-4.6\end{array}$ & $\begin{array}{c}\text { IV } \\
4 \\
3.20-3.25 \\
\end{array}$ & $\begin{array}{c}\text { VII } \\
5 \\
4.7-4.8\end{array}$ & $\begin{array}{c}\text { Vc } \\
6 \\
4.60-4.65 \\
\end{array}$ \\
\hline Pinus sylvestris t. & \multirow{31}{*}{$\begin{array}{l}\text { no pollen grains, } \\
\text { charcoal: } \\
\text { Quercus, Fraxinus, } \\
\text { Carpinus }\end{array}$} & \multirow{31}{*}{$\begin{array}{l}\text { no pollen grains, } \\
\text { coal dust }\end{array}$} & 213 & 210 & 160 & \multirow{31}{*}{ no pollen grains } \\
\hline Betula sp. & & & 25 & 101 & 72 & \\
\hline Ulmus & & & 11 & 65 & 46 & \\
\hline Quercus & & & 106 & 3 & 9 & \\
\hline Salix & & & 46 & 48 & 58 & \\
\hline Corylus & & & 17 & 5 & 4 & \\
\hline Alnus & & & 1 & 1 & 0 & \\
\hline Picea & & & 3 & 3 & 2 & \\
\hline Tilia & & & 2 & 0 & 0 & \\
\hline Larix & & & 0 & 1 & 0 & \\
\hline Poaceae & & & 20 & 17 & 35 & \\
\hline Cyperaceae & & & 4 & 3 & 5 & \\
\hline Artemisia & & & 4 & 4 & 5 & \\
\hline Brasicaceae & & & 10 & 5 & 1 & \\
\hline Rosaceae & & & 8 & 6 & 1 & \\
\hline Rubiaceae & & & 1 & 1 & 0 & \\
\hline Chenopodiaceae & & & 0 & 1 & 0 & \\
\hline Caryophyllaceae & & & 3 & 1 & 0 & \\
\hline Asteraceae & & & 0 & 1 & 1 & \\
\hline Apiaceae & & & 16 & 15 & 9 & \\
\hline Sparganium & & & 8 & 8 & 9 & \\
\hline Myriophyllum & & & 0 & 23 & 14 & \\
\hline Nuphar, Nymphaceae & & & 0 & 1 & 2 & \\
\hline Lemna & & & 1 & 0 & 0 & \\
\hline Humulus-Cannabis t. & & & 2 & 3 & 3 & \\
\hline Equisetum & & & 2 & 0 & 0 & \\
\hline Lycopodium & & & 1 & 0 & 0 & \\
\hline Polypodiaceae & & & 14 & 5 & 8 & \\
\hline Varia & & & 8 & 2 & 4 & \\
\hline Sum AP & & & 424 & 437 & 351 & \\
\hline Sum NAP & & & 102 & 96 & 97 & \\
\hline
\end{tabular}




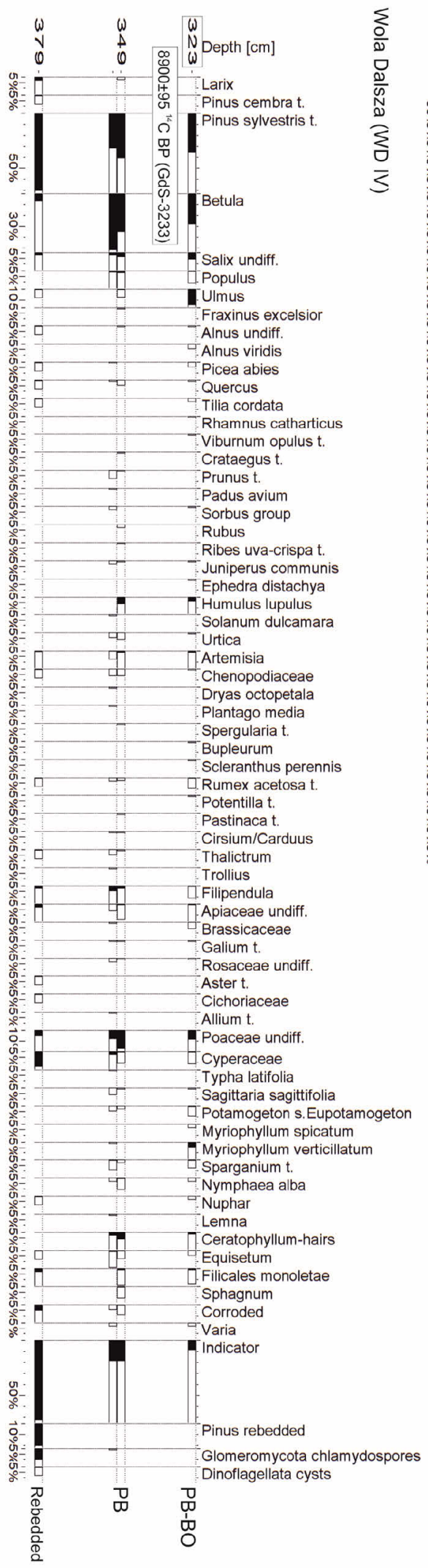

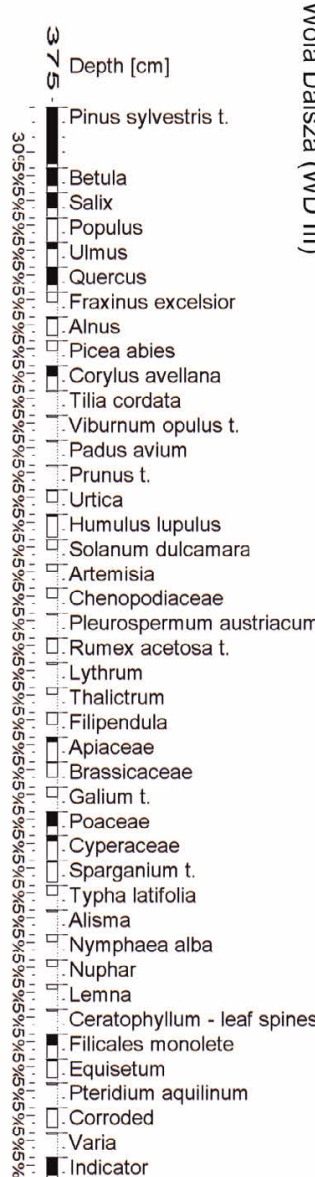

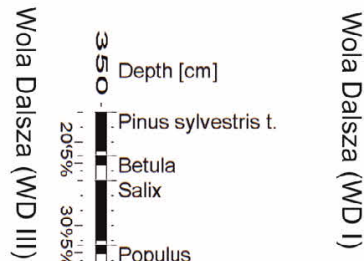

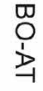

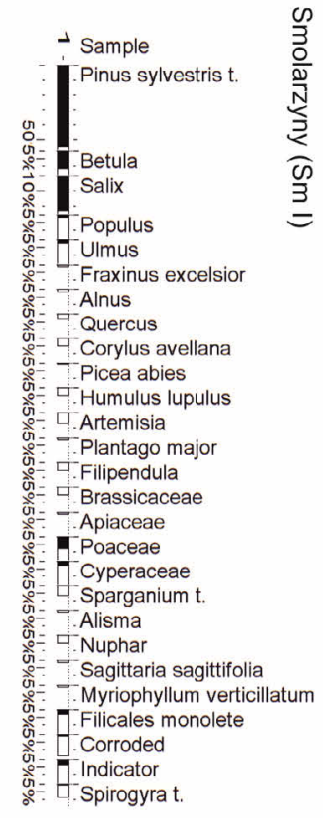

Fig. 4. Palynological diagrams of the Wola Dalsza and Smolarzyny sequences (analysed by P. Kołaczek). 
(Salix) pollen, which makes difficult the identification of the time of the peat deposition. The youngest is the sample from a depth of $3.75 \mathrm{~m}$ in the sequence WD III, which is characterised by a high content of oak (Quercus; ca. $10 \%$ ) and hazel (Corylus avellana) that can indicate the Boreal or the Atlantic Phase (Kołaczek, 2010, 2011).

\section{Anthracological analysis}

The sediment sample bearing charcoal fragments, taken from the $\mathrm{Vb}$ sequence at the Wola Dalsza site at a depth of $60-80 \mathrm{~cm}$, was used for the anthracological analysis (Fig. 2). The charcoal fragments were well preserved. Three tree taxa were recorded: Auropean hornbeam Carpinus betulus (3 fragments), European ash Fraxinus excelsior (13 fragments) and oak Quercus sp. (13 fragments). One hornbeam specimen was a fragment of a small branch. Each charcoal fragment is usually identified, regardless of its size. In the case of the sample from Wola Dalsza, the fragments larger than $1 \mathrm{~mm}^{3}$ were examined. The analysis were stopped after the examination of 30 fragments, because all taxa were recorded in the first four examined samples and no new taxon was found during the further observations. The charcoal fragments occurring in particular part of sediments often suffer subsequent fragmentation, which can bring about over-representation of one taxon in such agglomeration.

Consequently, the qualitative analysis of such specimen of charcoal seems to be more adequate than quantitative one.

In regard to the result of the anthracological analysis, particularly, on the basis of hornbeam occurrence that is characteristic for the Neoholocene forests, the sample age was ascribed to the Subboreal or/and Subatlantic Phases.

\section{Results of radiocarbon dating}

Six samples from the eight ones have sufficient weight for radiocarbon dating. The content of organic material in the samples bearing coal dust and charcoal was too small for the dating using the conventional technique (Table 1). The oldest alluvia within the $7-8 \mathrm{~m}$ high terrace are represented by channel gravels and sands with insert of clayey silts and wood fragments dated in the sequence $\mathrm{Vc}$ at a depth of $4.60 \mathrm{~m}$ at $11960-11395 \mathrm{cal}$ BP (probability level: 68.2\%; sample GdS-1920: $10100 \pm 140$ BP) (Table 1, Fig. 2). The peat deposited within an oxbow-lake, sampled in the boundary zone between the 7-8 $\mathrm{m}$ high terrace and the floodplain at a depth of $4.50 \mathrm{~m}$ in the sequence VIII was dated at 11 095-10 755 cal BP (probability level: 68.2\%; GdS3228: $9575 \pm 95$ BP), while the peat sample from the sequence IV within the floodplain, taken at a depth of $3.20-3.25 \mathrm{~m}$ in the northern part of the outcrop was dated at 10 195-9885 cal BP (probability level: $68.2 \%$; GdS3233: $8900 \pm 95$ BP) (Fig. 3). The tree trunk buried in the channel alluvia (sequence WD IX) at a depth of 5.80$5.90 \mathrm{~m}$ and dated at $10520-10300 \mathrm{cal}$ (probability level:
68.2\%; MKL-2786: BP $9290 \pm 50 \mathrm{BP}$ ) is also ascribed to the Preboreal Phase.

The amount of charcoal in the clay layer at the top of the 7-8 $\mathrm{m}$ high terrace, sampled at a depth of $0.6-0.8 \mathrm{~m}$ was too small for the conventional radiocarbon dating (Fig. 2). In the same sequence, at a depth of $1.5 \mathrm{~m}$, under the horizon of the silty-sandy flood rhythmite, coal dust occurs on the surface and inside hard clay aggregates, that resemble fossilized wood fragments.

In the northern part of the gravel pit within the floodplain, $c a .70 \mathrm{~m}$ from the present riverbed, the wood fragment sampled in the boundary zone between channel and overbank alluvia, at a depth of $3.00 \mathrm{~m}$, was dated at 8335-8155 cal BP (probability level 68.2\%; GdS-3230: $7390 \pm 80$ BP) (Fig. 2).

\section{Analysis of archival maps}

Analysis of cartographic materials proves that in the 70 -ties of the $19^{\text {th }}$ century the meandering Wisłok River channel of a width of 80-120 m, undercut the edge of the Vistulian terrace in a distance of $c a .1 \mathrm{~km}$ north of the current riverbed. In an area of the gravel pit the river channel that was moving toward the south (Fig. 5), eroded the Early Holocene organic sediments and simultaneously aggraded the floodplain, forming the youngest series of overbank sediments. At the turn of the $19^{\text {th }}$ and $20^{\text {th }}$ centuries a meander in the northern part of the valley (Fig. 5) was cut and a new, straightened river channel, $100-150 \mathrm{~m}$ wide, of meandering and braided character, was formed.

\section{DISCUSSION}

In the valley section between the villages of Trzebownisko and Łukawiec the floodplain occupies the area of a width of 200-300 m, whereas to the east of Łańcut its width increases up to $1.5 \mathrm{~km}$. The organic sediments occurring in its bottom at a depth of 3-4 m represent the

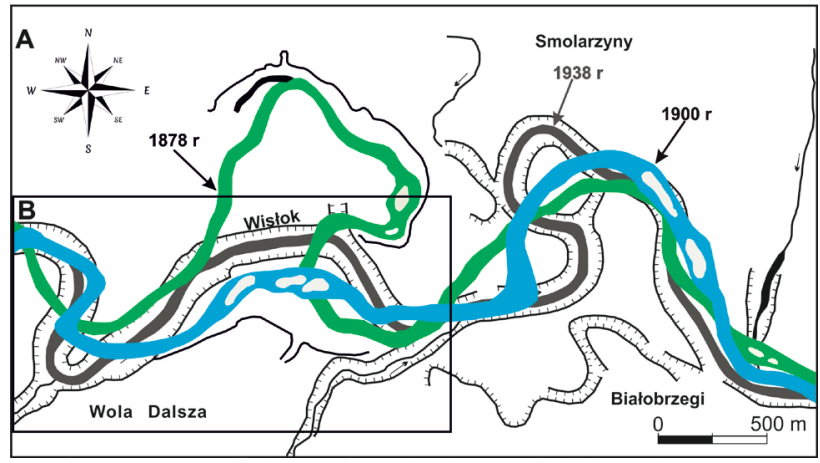

Fig. 5. Changes of the Wistok River channel during the $19^{\text {th }}$ and $20^{\text {th }}$ centuries (elaborated by S. Superson). A. Changes of the Wisłok River channel between Wola Dalsza and Białobrzegi, B. The area presented on Fig. $1 \mathrm{C}$ in detail. 
Interplenivistulian and are overlain by the Late Glacial and the Holocene alluvia (Gebica, 2004). To the east of the sites in the villages of Łąka and Łukawiec the Plenivistulian sediments are absent in the bottom of the $7 \mathrm{~m}$ high terrace, which suggests intensive downcutting of the Wisłok River in this part of the valley.

The preservation of the Early Holocene organic sediments forming the erosional bench of the floodplain (Figs. 1C, 2, 3) at a depth of 3.2-4.6 $\mathrm{m}$ indicates the predominance of lateral migration of river channel over its deepening. The occurrence of contemporary organic sediments in the southern and northern parts of the gravel pit as well as their similar stratigraphic position (Figs. $1 \mathrm{C}, 2)$ suggest the lack of fluvial activity in this zone, confirming the opinion of L. Starkel (1995), who postulated the stabilisation of river channels in that time. The environments suitable to the peat accumulation occurred at least from the beginning of the Boreal Phase (8900 \pm 95 BP, 10 195-9885 cal BP GdS-3233) probably up to the Atlantic Phase, as suggested by the palynological analysis (Fig. 3). Similar series of organic sediments were dated in the paleochannel of the Wisłok River at the sites in the villages of Wola Mała and Dąbrówki (Gębica et al., 2009) and in the Drwinka depression in the Vistula River valley (Starkel et al., 1991). At the other hand, the occurrence of channel alluvia with tree trunks dated to the Preboreal and Boreal Phases at the sites in Białobrzegi (Gębica, 2011; Gębica et al., 2014; Superson unpubl.) and Wola Dalsza villages (dated at $10100 \pm 140 \mathrm{BP}$, 11 960-11 395 cal BP, GdS-1920: (Fig. 2, Table 1), suggests the intensive fluvial activity of the Wisłok River and the occurrence of the peaty plain to the south of above mentioned sites. The tree trunks buried in the channel alluvia that are recorded in the WD IX sequence (Figs. 1B, 1C) probably are not redeposited, because at the mentioned above Białobrzegi site, the trunks occur at the similar depth $(5.8-6.2 \mathrm{~m})$ and their radiocarbon ages indicate the Preboreal Phase (9900-9100 BP) (Gębica, 2011; Gębica et al., 2014). The unequivocal determination of the period of the erosional truncation of the organic deposits is difficult. This could have started in the Atlantic Phase, as suggests the dating $7390 \pm 80 \mathrm{BP}$, (8335-8155 cal BP, GdS-3230). The dating of the deposition of blanket of overbank sediments is also problematic. In the vicinity of the current Wisłok riverbed the natural levee sediments, covered by silt-clay alluvia, occur. This allows to suppose, that they were deposited in the last several hundreds of years, similarly to the alluvia of the floodplain in Białobrzegi (Superson, unpubl.) and Budy Łańcuckie villages (Superson, 2014). The young age of the overbank sediments is also indicated by analysis of the cartographic materials from the $19^{\text {th }}$ and $20^{\text {th }}$ centuries, which document the Wisłok River channel avulsions in that time. The anthracological analysis of the charcoal sample from the top part of the terrace 7-8 $\mathrm{m}$ high, indicates the deposition of the silt-clay sediments during the Subboreal and Subatlantic Phases (Fig. 2). The charcoal particles which underwent long transport, would have become destroyed, therefore their agglomeration and accurate state of preservation in the sediment suggests their accumulation in situ.

\section{CONCLUSIONS}

1) The palynological analysis and the radiocarbon dating made it possible to determine the Early Holocene age (Preboreal and Boreal Phases) of the organic oxbow-lake sediments situated in the northern part of the Wisłok River valley.

2) The attempts to perform the conventional radiocarbon dating of the horizons with charcoal fragments failed owing to the small amount of organic material sampled and subsequently obtained after the benzene preparation in the laboratory. The anthracological analysis of the charcoal sample reveals the occurrence of the tree taxa typical for the Neoholocene, which suggests that the deposition of clay sediments occurred during the Subboreal and/or Subatlantic Phases.

3) The preservation of the Early Holocene organic sediments within the floodplain indicates the predomination of lateral migration of the river channel and the consequent erosion of the wide plain aggraded with flood (overbank) alluvia during the last 200 years. In the $20^{\text {th }}$ century the aggradation of the floodplain was synchronous with the deepening of the Wisłok River channel.

4) The radiocarbon ages obtained for the channel alluvia with tree trunks and peat horizons indicate the synchronicity of the organic deposition and the functioning of the active channel in the Early Holocene, which only partly confirm the hypothesis of L. Starkel (1995), that postulates the stabilisation of fluvial systems in that period.

\section{ACKNOWLEDGEMENTS}

The authors would like to thank to Dr. Magdalena Moskal del Hoyo from the W. Szafer Institute of Botany, Polish Academy of Sciences (PAS) in Kraków for the anthracological analysis and to Prof. Marek Krąpiec from the University of Science and Technology AGH in Kraków for the radiocarbon dating of wood samples as well as to Dr. Jan Urban from the Institute of Nature Conservation PAS in Kraków for the English translation of the text. We are also grateful to the anonymous reviewer for his/her valuable remarks which we used in order to improve our manuscript. 


\section{REFERENCES}

Berglund BE and Ralska-Jasiewiczowa M, 1986. Pollen analysis and pollen diagrams. In: Berglund $\mathrm{BE}$ and Ralska-Jasiewiczowa M, eds., Handbook of Holocene Palaeoecology and Palaeohydrology. J. Wiley \& Sons Ltd., Chichester-Toronto: 455-484

Bronk Ramsey C, Dee M, Lee S, Nakagawa T and Staff R, 2010. Developments in the calibration and modelling of radiocarbon dates. Radiocarbon 52(3): 953-961.

Chabal L, Fabre L, Terral J-F, Thery-Parisot I, 1999. L'Anthracolgie (Anthracolgy), In: A. Ferdière, Ch. Bourquin-Mignot, J.-E. Brochier, L. Chabal, S. Crozat, L. Fabre, J.-F. Terral, I. ThéryParisot (eds.), La Botanique. Collection "Archéologiques", Ed. Errance, Paris, 43-104.

Friedberg W, 1903. Atlas Geologiczny Galicyi. Tekst do zeszytu 16. Arkusze: Rudnik I Raniżów, Ropczyce i Dębica, Rzeszów i Łańcut. (Geological Atlas of Galicja) Wydawnictwo Komisyi Fizjograficznej Akademii Umiejętności, Kraków, 1-147.

Gębica P, 2004. Przebieg akumulacji rzecznej w górnym vistulianie w Kotlinie Sandomierskiej. (The course of fluvial accumulation durind the Upper Vistulian in Sandomierz Basin) Prace Geograficzne 193, Instytut Geografii i PZ PAN, Warszawa, 1-229.

Gębica P, 2011. Stratigraphy of alluvia and Holocene flood phases in the Lower Wisłok valley. Geographia Polonica 84 Special Issue p. I: $39-60$.

Gębica P, Bluszcz A, Pazdur A and Szczepanek K, 2002. Chronostratigraphy of Late Pleistocene fluvial deposits in the Wisłok river valley between Rzeszów and Łańcut, South Poland. Geochronometria 21: $119-128$.

Gębica P, Płoskonka D and Kalinovyč N, 2009. Lithology and age of the Holocene terrace in the Wislok river valley. Studia Geomorphologica Carpatho-Balcanica 43: 77-95.

Gębica P, Superson S, Hozer M and Bajda-Wesołowska A, 2014. Geoarcheologiczny zapis ewolucji doliny Wisłoka na przykładzie stanowiska $\mathrm{nr} 19$ w Białobrzegach (Geoarchaeological record of the evolution of the Wistok valley based on the site No. 19 in Biatołobrzegi). Materiaty i Sprawozdania Rzeszowskiego Ośrodka Archeologicznego 35: 217-227.

Klimek K, Łanczot M and Nogaj-Chachaj J, 2006. Historical deforestation as a cause of alluviation in small valleys, subcarpathian loess plateau, Poland. Regional Environmental Change 6 (1-2): 52-61, DOI 10.1007/s10113-005-0008-3.

Kolaczek P, 2007. Late Glacial and Holocene vegetation changes in the western part of Rzeszów Foothills (Sandomierz basin) based on the pollen diagram from Krasne near Rzeszów. Acta Palaeobotanica 47: 455-467.

Kołaczek P, 2010. The development of Late Glacial and Holocene vagatation and human impact near Grodzisko Nowe in the Lower San Valley (Sandomierz Basin, south-eastern Poland). Acta Palaeobotanica 50: 101-117.

Kołaczek P, 2011. 12 Millennia of climatic and human induced vegetation changes in the Lower San Valley near Jarosław (SE Poland) in the light of pollen analysis. Studia Quaternaria 28: 25-39.

Kołaczek P, Zubek Sz, Błaszkowski J, Mleczko P and Margielewski W, 2013. Erosion or plant succession - How to interpret the presence of arbuscular mycorrhizal fungi (Glomeromycota) spores in pollen profiles collected from mires. Review of Palaeobotany and Palynology 189: 29-37, DOI 10.1016/j.revpalbo.2012.11.006.

Laskowska-Wysoczańska W, 1971. Stratygrafia czwartorzędu i paleogeomorfologia Niziny Sandomierskiej i Przedgórza Karpat rejonu Rzeszowskiego. Studia Geologica Polonica 34: 1-109.

Pazdur A, Fogtman M, Michczyński A and Pawlyta J, 2003. Precision of ${ }^{14} \mathrm{C}$ dating in Gliwice radiocarbon laboratory. FIRI Programme. Geochronometria 22: 27-40.

Pawlyta J, Pazdur A, Rakowski AZ, Miller BF and Harkness DD, 1998. Commissioning of a Quantulus 1220 liquid scintillation beta spectrometer for measuring $14 \mathrm{C}$ and $3 \mathrm{H}$ at natural abundance levels. Radiocarbon 40 (1): 201-209.
Reimer PJ, Bard E, Bayliss A, Beck JW, Blackwell PG, Bronk Ramsey C, Grootes PM, Guilderson TP, Haflidason H, Hajdas I, HattŽ C, Heaton TJ, Hoffmann DL, Hogg AG, Hughen KA, Kaiser KF, Kromer B, Manning SW, Niu M, Reimer RW, Richards DA, Scott EM, Southon JR, Staff RA, Turney CSM and van der Plicht J, 2013. IntCal13 and Marine13 Radiocarbon Age Calibration Curves 0-50,000 Years cal BP. Radiocarbon 55(4): 1869-1888.

Schweingruber FH, 1982. Mikroskopische Holzanatomie, Komisionverslag/F. Flück-Wirth (Microscopic wood anatomy, comissioning / F. Flück-Wirth), Internationale Buchhandlung für Botanik und Naturwissenschaften, CH-9053 Teufen AR.

Schweingruber FH, 1990. Anatomie Europäischer Hölzer (Anatomy of European Woods). Paul Haupt Berne und Stuttgart Publishers, Bern-Stuttgart.

Special map of the Austro-Hungarian Monarchy 1: 75,000, ark. Rzeszow and Lancut, 1878. Kaiserlich und Königlich Militaergeografisches Institut. Military-Geographic Institute, Wien.

Special map of the Austro-Hungarian Monarchy 1: 75,000, ark. Rzeszow and Lancut, 1900. Kaiserlich und Königlich Militaergeografisches Institut. Military-Geographic Institute, Wien.

Starkel L, 1960. Rozwój rzeźby Polskich Karpat fliszowych w holocenie. (The development of the flysch Carpathians relief during the Holocene) Prace Geograficzne 22, Instytut Geografii i PZ PAN, Warszawa, 1-239.

Starkel L, 1972. Kotlina Sandomierska (Sandomierz Basin), in Klimaszewski, M. (ed.), Geomorfologia Polski (Geomorphology of Poland), vol. 1, Wydawnictwo Naukowe PWN, Warszawa, 138166.

Starkel L, 1995. The place of the Vistula river valley in late Vistulianearly Holocene evolution of the European valleys. In: Frenzel B. (Ed.) European river activity an climatic change during the Lateglacial and early Holocene. Special Issue: ESF Project, European Palaeoclimate and Man 9: 75-88.

Starkel L, 2001. Historia doliny Wisły od ostatniego zlodowacenia do dziś. (Evolution of the Vistula river valley since the last glaciation till present) Monografie IGiPZ PAN, 1, Warszawa, $263 \mathrm{pp}$.

Starkel L, Gębica P, Niedziałkowska E and Podgórska-Tkacz A, 1991. Evolution of both the Vistula floodplain and Lateglacial - early Holocene palaeochannel systems in the Grobla Forrest (Sandomierz Basin), in: L. Starkel (ed.) Evolution of the Vistula river valley during the last 15000 years, IV, Geographical Sudies, Special Issue $6,87-99$.

Strzelecka B, 1958. Historyczna dokumentacja niektórych młodszych zmian hydrograficznych na brzegu Karpat. (Historical documentation of some younger hydrographical changes of the margin of Carpathians) Czasopismo Geograficzne 29(4): 455-472.

Superson S, 2014. Znaczenie datowań archeologicznych i radiowęglowych w określaniu wieku współczesnych aluwiów powodziowych na stanowisku Budy Łańcuckie III. (The importance of archaeological and radiocarbon datings in determininig the age of modern alluvial flood deposits in the Budy Lańcuckie site No. III) Materiaty i Sprawozdania Rzeszowskiego Ośrodka Archeologicznego 35: 227-237.

Superson S, Gębica P, Michczyński A, Kołaczek P and Szczepanek K, 2016. Chronostratigraphy of the Holocene alluvia of the Wisłok river in the light of the radiocarbon datings and palynological analysis (example from Wola Dalsza sandpit near Lańcut, Sandomierz Basin), Conference Abstracts Series, Geochronometria 1: $88-89$.

Topographic map on the scale 1: 100000 ark. Rzeszów (P48 S34), 1938. WIG 1938.

Tudyka K and Pazdur A, 2010. Radiocarbon dating of peat profile with metallurgy industry of evidence. Geochronometria 35: 3-9, DOI 10.2478/v10003-010-0007-3.

Tudyka K, Bluszcz A, Kozłowska B, Pawlyta J and Michczyński A, 2015. Low level $14 \mathrm{C}$ measurements in freshly prepared benzene samples with simultaneous $214 \mathrm{Bi} / 214 \mathrm{Po}$ pairs counting for routine 222Rn contamination correction. Radiation Measurements 74: 611, DOI 10.1016/j.radmeas.2015.01.010. 